\section{Missiology as social justice}

A contextual reading of the mission

of Christ in Luke 4:16-19

\section{Mooko S Kgatle ${ }^{1}$}

\section{Abstract}

In honour of Professor Nico Botha, this article is a contextual reading of Luke 4:1619. The article addresses social issues such as poverty, captivity, oppression and bondage, not only as the mission of Christ but in the context of the poor and the marginalised in the City of Tshwane. These are the same social ills that the homeless in the City of Tshwane experience in their everyday life. Literature review on the topic of social justice demonstrates a relationship between social justice and social poverty. It also demonstrates that homelessness is associated with social factors such as unemployment, poverty and inequality. However, the literature review on social justice demonstrates the research gap in studying the subject from Luke 4:16-19. Equally so, the context of Luke 4:16-19 demonstrates a research gap in applying the text in the context of the homeless in the City of Tshwane. To address the two research gaps, this article reads Luke 4:16-19 in the context of the homeless in the City of Tshwane.

Keywords: Social justice; City of Tshwane; Luke; homelessness; Nico Botha

\section{Introduction: Missiology as social justice}

In honour of Prof Nico Botha, this article engages in missiology as social justice in Luke 4:16-19 and in the context of the homeless in the City of Tshwane. According to Botha, social justice remains topical in Christian mission in general and the academic discipline of missiology in particular (2009:2). Therefore, missiology as social justice, according to Botha, is not about tangentially looking at justice issues from the perspective of the gospel, but to express the gospel in a manner that will reveal justice issues (2010:186). This is exactly what this article tries to achieve by reading Luke 4:16-19 in the context of the homeless in the City of Tshwane. Botha reiterates that missiology as social justice is informed by social analysis to assist the poor in understanding their situation and its root causes and the reading of the Bible in the context of their situation (2010:189). Therefore, Botha sees a need for a contextual theology emerging from the poor, speaking to their miserable situation of destitution, but also unearthing their new and creative forms of solidarity, joy and

\footnotetext{
Dr M.S. Kgatle is Senior Lecturer in the Department of Christian Spirituality, Church History and Missiology, University of South Africa, Pretoria, South Africa. He can be contacted at Kgatls@unisa.ac.za.
}

hope (2010:193). Contextual theology, such as the political and socio-economic oppression of people, the poor, women in their struggle for emancipation, children, specifically those at risk, can hardly be ignored by missiology (2011a:23).

\section{Literature review: social justice}

Social justice is a state of affairs (either actual or ideal) in which benefits and burdens in society are dispersed in accordance with an allocation principle (or set of principles); procedures, norms, and rules that govern political and other forms of decision making preserve the basic rights, liberties, and entitlements of individuals and groups; and human beings (and perhaps other species) are treated with dignity and respect, not only by the authorities but by other relevant actors, including fellow citizens (Jost \& Kay, 2010:1122). Social justice in the context of the homeless, means that an individual or family, lack a fixed, regular, and adequate night-time residence; an individual or family who will imminently lose their primary night-time residence; unaccompanied youth and families with children who have lived for a long period of time without living independently in permanent housing and an individual or family fleeing, or attempting to flee, domestic violence and other situations of violence (Anderson, 2013:462). Homelessness means a loss of social identity - loss of permanent address, work, school, relationships and a place to call one's own - and can go as far as meaning a loss of a sense of self (McCarthy, 2013:55).

Social justice in the context of the homeless has been studied. Anderson (2013), for example, looked at the ways in which homelessness could be prevented by providing housing and education for young people. Anderson further argued that implementation of the strategic plan should provide more collaboration between housing and education agencies than is currently included. To achieve the goal of ending and preventing homelessness among families, youth, and children, it is important that supportive housing units effectively deliver educational resources to homeless youth to reduce the likelihood that they become homeless adults. In their article 'Youth homelessness: A social justice approach', Watson and Cuervo (2017:1) argued that social justice approaches that work towards eliminating youth homelessness with a sole focus on material needs overlook the significance of nonmaterial aspects, such as the impact of social exclusion and stigma on individuals' subjectivities. Watson and Cuervo continue to state that the lack of social legitimacy associated with homelessness is exacerbated under neoliberal conditions, with the shift from social to individual responsibility positioning those unable to achieve the normative transition to adulthood as social failures. Shinn (2010:20) agrees that patterns of social exclusion are related to homelessness at two levels: they influence the overall generosity of social welfare programmes and they affect the ability of particular households to access income, wealth, jobs and housing. Structural 
factors such as poverty and social exclusion relate to individual's vulnerabilities to produce and maintain homelessness.

Eberle, Kraus, Serge, and Hulchanski (2001) demonstrate the relationship between homelessness and the health, social services and criminal justice systems. Mago, Morden, Fritz, Wu, Namazi, Geranmayeh, Chattopadhyay and Dabbaghian (2013) state that the forces which affect homelessness are complex and often interactive in nature. Social forces such as addictions, family breakdown, and mental illness are compounded by structural forces such as lack of available low-cost housing, poor economic conditions, and insufficient mental health services. Together, these factors impact levels of homelessness through their dynamic relations. Historic models which are static in nature have only been marginally successful in capturing these relationships. In his article 'Social justice, respect, and meaning-making: Keys to working with the homeless elderly population', Proehl (2007:301) mentions that elderly homeless people need special attention as their age makes them especially defenceless, their options for reintegrating into society are few, and their physical ability to withstand the hardships of being homeless or living in shelters is limited. Henwood, Wenzel, Mangano, Hombs, Padgett, Byrne, Rice, Butts and Uretsky (2015:3) argue that homelessness and housing instability are substantial problems that afflict a diverse group of subpopulations such as families, youth, veterans, and chronically homeless single adults. Ending homelessness for each of these populations may require tailored interventions that are responsive to specific individualised needs.

Homelessness in a city context in South Africa, according to Mashau (2014:21), knows no boundaries of race, age, gender and class, or even nationality. The homeless population is not homogenous. Blacks, whites, men, women, youth, children, locals and foreigners have all become the faces of homelessness. Homeless people can be identified in a South African metropolitan context, according to Du Toit (2010:3), as detached homeless persons, temporary overnight sleepers (including evictees and 'weekday' homeless persons), and informal settlement dwellers. The first two of these three groups can be referred to collectively as 'street homeless persons' since they typically live on the streets of metropolitan municipalities. Du Toit further adds that the South African government consider the following in order to address the problem of homelessness:

- View homelessness primarily as an issue of lack of employment and affordable housing and locate the responsibility with local economic development and housing departments.

- Consolidate existing homelessness policies, strategies and programmes and focus more on implementing and monitoring programmes, provided that such programmes include substantive spatial and physical interventions.
- Provide shelters for the homeless and affordable rental housing close to inner cities, industrial parks and other places of employment, with affordable self-owned housing close to townships and other residential areas.

- Plan and design urban spaces and settlements to be more sensitive to the needs of vulnerable groups, including the homeless.

Literature review on the topic of social justice in the context of the homelessness demonstrates the relationship between social justice and homelessness. It further demonstrated the relationship between homelessness and social factors like poverty, unemployment and inequality. It is for these social factors that scholars such as Watson, Cuervo and Shinn suggest that social exclusion is the cause of homelessness. In addition, this literature review demonstrates a research gap in studying the subject of social justice from a Biblical point of view, particularly Luke 4:16-19. To address this research gap, this article studies the context of Luke 4:16-19 and applies it to the homeless in the City of Tshwane. This will be achieved by looking at the theological reflection on Luke 4:16-19.

\section{Luke 4:16-19}

The passage of scripture for this chapter is Luke $4: 16-19^{2} .16$ " ... and he came to Nazareth, where he had been brought up. And as was his custom, he went to the synagogue on Sabbath day, and he stood up to read. 17 ... and the scroll of the prophet Isaiah ${ }^{3}$ was given to him. He unrolled the scroll and found the place where it was written, $18 \ldots$ the spirit of the Lord is upon me, because he has anointed me to proclaim good news to the poor $(\pi \tau \omega \chi 0 \tilde{\circ} \varsigma)$. He has sent me to proclaim liberty

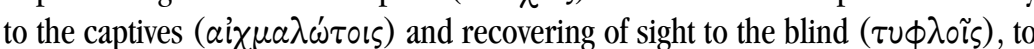

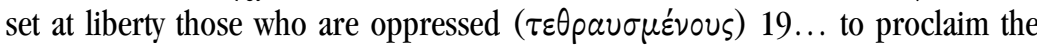
year of the Lord's favor ( $\delta \varepsilon x \tau o ́ v)$ ".

\section{The theological context of Luke 4:16-19}

According to Luke, immediately after Jesus' sojourn and temptation in the desert, he returned to Galilee "in the power of the Spirit" (4:14) and began teaching in the synagogues. In the first part of the important events described in Luke

\footnotetext{
2 Jesus read a scripture from Isaiah 61:1; The Spirit of the Lord God is upon me, because the Lord has anointed me to preach good tidings to the poor. He has sent me to heal the broken-hearted, To proclaim liberty to the captives, And the opening of the prison to those who ar bound; Trom To proclaim the acceptable year of the Lord, And the day of vengeance of our God; To comfort all who mourn.

3 There is a strong connection between Luke 4:16-19 and Isaiah 61:1-2 because Jesus directly read from the text in Isaiah 61:1-2. However, for the purpose of this chapter, one will concentrate on the
} text in Luke 4:16-19. 
4:16-19, Luke reports Jesus teaching in his home city of Nazareth. Standing to read from the scroll of Isaiah, ${ }^{4}$ Jesus found what we know as Isaiah 61:1-2a and read it aloud. In addition to reading from Isaiah 61, Jesus adds a line from Isaiah 58:6 to his proclamation (Bruno, 2010:84). Luke 4:16-19 summarises Jesus' ministry as it is explained in Luke-Acts. Luke emphasises the fact that Jesus was anointed with the Holy Spirit. Luke recognises the connection that exists between "being anointed" and "royal messiah" (Siame, 2016:21). In addition, Luke 4:16-19 is about the identity of Jesus, the good news to the poor, freedom for the prisoners, recovery of sight for the blind, release for the oppressed and proclaiming the year of the Lord's favour (Nwaomah, 2005:51).

Luke 4:16-19 is placed just after the Spirit's descent on Jesus - his empowering for mission - and the temptation, which pictures the missionary methods and tasks Jesus refused to use and accomplish, this text inserted between two editorial summaries (Luke 4:14-15 and Luke 4:31-32), has all the characteristics of a programmatic manifesto or policy document. Luke 4:16-19, according to Gang (2010:2), can be read as the Spirit's mission manifesto revealing the Spirit's priorities as formulated through a combination of texts taken from the Prophet Isaiah. Gang further adds that Luke 4:16-19 reveals something of Jesus' own priorities and shows how he understood his specific role within God's mission.

This passage contains the theme of his work - it unveiled his role as the Messiah, long awaited by the Israelites, and demonstrated the universality of salvation. It was also rich in its consciousness of social concern. For example, Luke 4:18 mentions the poor, the captives, the blind and the oppressed - people who were discriminated against and unfairly treated. These titles bear much social character. Jesus salvation was to proclaim to these people good news, release, recovery of sight, and freedom. According to Powell (1989:39), Luke 4:16-19 is not only about a spiritual redemption but also about social and political dimensions, especially towards the poor, the captives, the oppressed, and the weak in society

It is clear, then, according to Robbins (1996:89) that the Lukan story particularly in Luke 4:16-19 is social in nature. Preaching good news to the poor, giving sight to the blind, healing lepers, and raising the dead becomes a social responsi-

It seems apparent that the Kingdom of God that Jesus announced was clearly rooted in Israel's Jubilee tradition. Without a doubt, Jesus appealed to the Sabbath - Jubilee story of release at the outset of this mistry when he chosen text was the afore-mentioned Isaiah 61.1-2, a text that at least twice uses the language of release. This quotation from Isaiah found in Luke is a composite text, where one phrase from Isaiah 61:1 has been omitted and another phrase from Isaiah $58: 6$ has been inserted. The quotation is also abridged in that the last two phrases of Isaiah 61:2 and appears to have been omitted (Hurkmans, 2012:28). bility in Jesus' activity as the story unfolds. Steyn and Yousaf (2010:156) add that Luke wants to point to the Spirit-filled Jesus who is bearing down on His goal in a focused way; the one who is fulfilling the prophecies to bring the year of grace to the marginalised. The context of Luke 4:16-19 demonstrates that the text is about the Jesus mission to the world. This mission is enabled by the power of the Holy Spirit and the anointing. It is not only a redemptive mission but also the mission with social responsibilities to the poor, oppressed, sick, prisoners and the vulnerable in society. The social dimension of Luke 4:16-19 has been studied widely, what is new in this chapter is that these social dimensions in Luke 4:16-19 are applied to the context of the homeless in the City of Tshwane. This shall be done by first reflecting theologically on Luke 4:16-19.

\section{Social justice in Luke 4:16-19}

5.1 Good news to the poor

Luke 4:18a: "The Spirit of the Lord is upon me, because He has anointed me to proclaim good news 5 to the poor". ${ }^{6}$

Jesus states that the Spirit of the Lord has anointed him to preach the good news. What is interesting for this chapter is the recipients of this good news, the poor. The poor in this context means destitute, those who are too poor to engage in the act for aims for survival. The word poor as used in Luke 4:18 refers to people who are vulnerable and marginalised as opposed to spiritual poverty. ${ }^{7}$ Furthermore, it refers to people who are indebted because of social factors like inequality and unemployment. ${ }^{8}$ Therefore, proclaiming good news to the poor in Luke 4:18 is not only an act of preaching the Bible, but also an act of taking care of such vulnerable people.

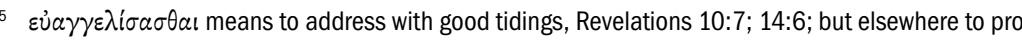
claim as good tidings, to announce good tidings of Luke 1;19; to address with good tidings, Acts 13:32; 14:15, to address with the Gospel teaching, evangelise, Acts 16:10; Galatians 1:9; to announce good tidings of the Gospel, Luke 4:18; 9:6; pass. To be announced as good tidings. Luke 16:16; to be addressed with good tidings, Matthew 11:5; Luke 7:22 and Hebrews 4:2.

$16: 16$; to be addressed with good tidings, Matthew 11:5; Luke $7: 22$ and Hebrews $4: 2$.
6 Luke uses the word $\pi \tau \omega \chi 0$ î 5 it speaks about the poverty that is used to a level of beggary, mendicant Luke uses the word $\pi \tau \omega \boldsymbol{\alpha}$ ois it speaks about the poverty that is used to a level of beggary, mendicant;
poor, indigent. In Matthew, 19:21; 26:9,11 it is used more as spiritually poor. In revelation 3:17, by implication it is used to refer to a person of a low condition. In Matthew 11:4; Luke 4:18; 7:22 is used as beggarly or a sorry person. In Galatians 4:9 it is used to refer to a person of lowly heart (for more on the Greek word $\pi \tau \omega$ xoĩs see Mounce \& Mounce, 2008:1155)

7 However, the poor could also mean in all ages, who thought rich in this world, are conscious of their spiritual depravity (Matthew 5:3). This might conform to the "pious poor" of the Old Testament (2 Samul 22:28; Psam 14:22,24; Amos 8:4; Isain 3:14,15). Such possesses an attude of humil-

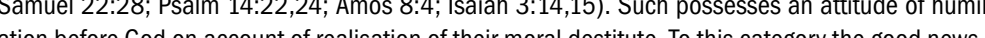
ation before God on account of realisation of their moral destitute. To this category the good news is the provision of hope and salvation from their unpleasant situation in the person and activities of the Messiah (Nwaomah, 2005:53)

8 Poverty arises not from personal laziness or deficiency, but from social factors such as unequal distribution of power, denial of opportunities, unfair distribution of resources, etc. (Prior, 1995:194)
} 
The question is: What is good news to somebody who has not eaten food for several days? What is good news to a man living on the streets? What is good news to a beggar on the streets? What is good news to the unemployed?

Hurkmans (2012:97) opines that "good news to the poor" is to take care of such people. The gospel is genuinely good news for the poor, and for all those who have debts which result in their own captivity and which deny them fullness of life. However, Hurkmans cautions that those who profited from these patterns of indebtedness or „,business as usual“ would not receive this as good news. The privileged people would have their security through debt-acquired wealth threatened.

To preach good news to the poor is a genuine concern for the poor and the oppressed, it needs to be consistent in words and deeds. As the Body of Christ, the Church needs to set an example. To really help these people is to oppose or work to eliminate those cultural or social policies which make people poor or oppressed. Otherwise, we participate in the roll of reinforcing these policies and making people suffer further (Prior, 1995:194). By proclaiming that "the Spirit of the Lord is upon me, for He has anointed me to preach the good news to the poor", DeuteroIsaiah was announcing the words of comfort to various categories of vulnerable people who live in post-exilic communities in Jerusalem. In Luke's context, Jesus' good news was also targeted for the vulnerable people, the poor, who were vulnerable due to poverty caused by social classification (Siame, 2016:13).

The gospel is good news to the poor because it is: a message of liberation - the gospel is the promise of liberation from all those things, personal and social, that enslave the people; a message of grace - God's promise of forgiveness and liberation does not depend on one's status, education, or wealth; a message of community - the coming liberation of God is anticipated in the liberating relationships of the Christian community (Chester, 2013:89). The poor need such liberation from the enslavement of debt and other forms of bondage.

The Biblical imperative to care for the poor and the weak in a manner that empowers them and values their worth and dignity as persons has not changed. What distinguishes followers of Christ is a fundamental commitment to continually work to support the most vulnerable members of society for all are God's children and made in God's image. Whether it is organising a soup kitchen or challenging tax policies, the call of God for Christians is to bring good news to the poor. This is the mission for social justice as well (Poe, 2002:76). The church should make a commitment even from a local assembly level to take care of the needs of the poor in making the gospel relevant to such groups of people.

The "Nazareth Manifesto" (Luke 4:16-19; Isaiah 61:1-2; 58:6) which should also be adopted as "church Manifesto" pushes the church in the direction of a deliberate effort towards the marginalised and outcast as opposed to the restrictions of
Pharisaic religious teaching - prevalent in the church today. Has the church moved from Pharisaic persuasion to Christ's? Is the church transformational enough in its thinking, teaching and praxis? (Emedi, 2010:125). The church needs to be theoretical and practical in dealing with the poor. Preaching good news should mean taking care of the poor

5.2 Liberty to the captives

Luke 4:18b: "He has sent me to proclaim liberty to the captives". ${ }^{9}$

The captives that the text refers to are not the murderers and psychopaths that one might imagine. In the Old Testament prisoners were not criminals or convicts. Incarceration was not the penalty for civilian criminal acts. Rather, "they were prisoners of war or of conscience, debtors, captives, hostages, victims of militarism or government oppression". This is not to say that all prisoners in Israel's history were misunderstood "victims of the system", but that the majority of those who were incarcerated were themselves casualties of injustice on some level (Hurkmans, 2012:19). In addition, the word "captive" was a political term, the characteristic for captives was loss of freedom. The release of captives was to release them from situations of no freedom (Prior, 1995:113).

Liberation for the captives, initially has reference to the Babylonian captivity who anticipated freedom from the yoke of captivity. The liberation talked about in Luke 4:18 must be understood and interpreted in a physical sense rather than spiritual, because the context has to do with the burden of debt that the poor people accumulated in their respective communities. Luke's community might have undertaken the idea of paying debts on behalf of the indebted people as a way of releasing or liberating them from imprisonment (Siame, 2016:17). In this context, it conveys the power of the gospel to liberate the indebted from the bondage of debts. The motif of debts as bondage to the devil is demonstrated in Christs' teaching in the fourth gospel of John and taken over by Paul who expands it in Romans 6:15, 16 (Nwaomah, 2005:54).

\subsection{Recovery of sight to the blind}

Luke 4:18b: "Recovering of sight to the blind". ${ }^{10}$

"Proclaim recovery of sight to the blind": the blind or the handicapped were discriminated against everywhere, today as well as yesterday. To recover their sight was to stop them from being further discriminated against (Prior, 1995:113). The blind were people with impaired social standing in the community, but with Jesus

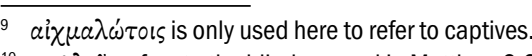

${ }_{10} \tau \cup \phi \lambda o i ٓ s$ refers to the blind as used in Matthew 9:27, 28; 11:5; 12:22. In Matthew 15:14; 23:16, it is used to refer to people who are mentally or spiritually blind. 
the same people are those "for whom God's reign as Jubilee brings good news and healing (Hurkmans, 2012:32). The proclamation of "sight to the blind" is a straightforward matter that refers to the physical healing of the blind people in the eastern part of the Roman Empire. The life of the blind people in this particular place was entirely dependent on begging; hence they needed empowerment ( $\mathrm{Si}$ ame, 2016:17).

The blind, in the mission of Jesus, received the recovery of sight. This aspect of the mission of Christ must first be a reference to his miraculous work in restoring the sight of those who are literally blind. To such he returned their sight (Luke $7: 22)$. Upon these people, the prophecy was literally fulfilled to demonstrate the arrival of the reign of God over Satan. However, those who need return of sight include those who are spiritually blind. All who are spiritually blind to the provision in the person and activities of Jesus as the Messiah need the sight of faith to appreciate the magnitude of the provision (Nwaomah, 2005:53).

\subsection{Liberty to the oppressed}

Luke 4:18b: "To set at liberty those who are oppressed". ${ }^{11}$

The oppressed who are mentioned in the mission statement were probably rural peasants who in most cases were unable to pay their debts and taxes which they owed the patrons and the Roman government. In this society, indebtedness and poverty in the periphery was mainly caused by factors such as peasants having a large number of dependents to take care of - in the 1st century Mediterranean world people were group oriented and lived communally (Siame, 2016:67). "Let the oppressed go free": although Jesus had not defined who the oppressed were, it can be reasonably assumed that the oppressed not only include those being spiritually oppressed but those unfairly treated by societies systematic structures (Prior, 1995:114).

A way that churches can proclaim and offer "release" to the oppressed is through the support of refugees and their families. Thankfully, those passages concerning the Biblical Jubilee include special mention of foreigners and resident aliens as groups of people who are vulnerable and in need of protection. Exodus 23:9 states; "You shall not oppress a resident alien; you know the heart of an alien, for you were aliens in the land of Egypt". Caring for refugees was deeply rooted in Israel's own story of "release". A "resident alien" in this context was someone from a different ethnic background who had taken up long-term residence in Israel. Yet, as part of the Jubilee mandate, such people were to be included in God's liberating vision. To

\footnotetext{
${ }^{11} \mathrm{~T} \varepsilon \theta$ pav $\mu \varepsilon^{\prime} v 0 u s$ is only used here to refer to the people who are breaking, shivering, shattered, and
} crushed by cruel oppression. a remarkable degree, the immigrant was treated before the law in exactly the same way as an Israelite" (Hurkmans, 2012:52).

Release for the oppressed is an integral part of the components of the good news that is being heralded to the poor in the programmatic declaration of the mission of Christ and by extension of the church. Sin oppresses and being under the oppression of demons could be likened to being trapped in a prison of despair and pain. In addition, to set them free is to release them from the pressure of sin and give them consolation and liberate them from the yoke of the demons. Jesus adequately demonstrated this in teachings and miracles (Nwaomah, 2005:54). The oppressed need liberty so that they can be released from such oppression. The body of Christ should not practice worldly systems that put people in oppression like debts and other factors.

\subsection{The year of the Lord's favour}

Luke 4:19: "To proclaim the year of the Lord's favour". ${ }^{12}$

The year acceptable to the Lord also refers to the Year of Jubilee in the Old Testament ${ }^{13}$. Its pronouncement marked the reversal of the rich and poor, it was a time of release for those who were forced into slavery and the release of land which was lost due to poverty to the original owners. It was a time of erasing debts and a time of letting the land lie. Fallow Jubilee Year was built on a spiritual foundation that was premised on strong commandment of releasing people who were in bondage (Siame, 2016:28). In addition, the Biblical Jubilee holds out the promise of forgiveness for all and the hope of a future for the poor, the oppressed, and the marginalised. The Old Testament message of Sabbath-Jubilee forgiveness was taken up by Christ himself as a central motif in his life and teaching. Forgiveness of debts provides the foundation upon which the Kingdom of God was to be constructed. What began with the economic forgiveness of debilitating loans, has grown to embrace

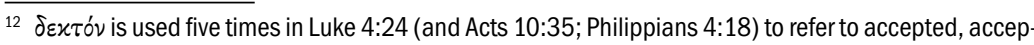
table, agreeable, approved;. It is also used to refer to divine acceptance, propitious in Luke 4:19 and 2 Corinthians 6:2. In Luke's version, Jesus proclaims the Year of that is accepted or acceptable to the Lord. In Isaiah's version this is the Year of Jubilee (Mounce \& Mounce, 2008:1072).

${ }^{13}$ "Proclaim God's Year of Mercy (Jubilee Year)“: Prophet Isaiah may be pointing to a particular incident, or a vision held by the Israelites before or after their defeat by Babylon (6). The Year of Mercy finds it origins in Leviticus 25:1-17. According to the Bible Jews took every seven years as a cycle. In the first six years, sowing pruning the vineyard and harvesting were allowed. The seventh year was the Sabsix years, sowing, pruning the vineyard and harvesting wa

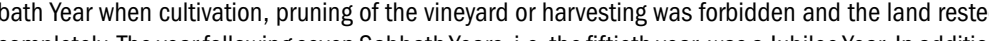
completely. The year following seven Sabbath Years, i.e. the fiftieth year, was a Jubilee Year. In addition to forbidding of sowing and harvesting, only wild produce could be eaten, all debts were cancelled, all pawned properties were returned, sold land was given back to the original owner, slaves regained their freedom and returned home, etc. (Prior, 1995:114). 
the fullness of release. As such, the church's mission today should be characterised by forgiveness in all its fullness (Hurkmans, 2012:110).

It is quite clear that in Luke's account of this event it is emphasised. Given the links to the Jubilee Year in Isaiah 61, it is likely that Luke's emphasis on liberty has a similar link to the Jubilee. The quotation in Luke 4 ends with the mention of the Lord's favour and omits the parallel reference to retribution from the Lord found in Israel 61:2b (Bruno, 2010:97). Therefore, the year of the Lord's favour means the era of salvation or the age of the gospel. The allusion here is obviously to the Year of Jubilee in the Jewish calendar. In this year, slaves regained their freedom, debt relief was given to the poor and lands bought or taken in pledge were released to their original owners. Similarly, in the era of the gospel, the acceptable year of the Lord, the poor, the prisoners or captives, the blind, the oppressed who are the unfortunate of the world, and those who realise a sense of dependence on God may expect consolation, comfort, forgiveness and liberation from the forces that confront them (Nwaomah, 2005:55).

\section{Social justice in the context of the homeless \\ in the City of Tshwane}

Botha challenges any theologian or pastor, minister or priest in South Africa to identify with categories of the struggling poor, unemployed, illiterate, landless and marginalised people (2010:189). According to Botha, poor people do not need sophisticated tools of analysis to tell them the reason that some are rich while they are poor, the reason that some own the land and others are landless (2010:189). Poor people need others who can identify with their context (2011b:13). To read Luke 4:16-19 in the context of the homeless in the City of Tshwane is to interpret the poor in the text as not only poor in the spirit but socially poor. They need basic things like shelter, food and water. Most of them are destitute and vulnerable. They are unemployed and exposed to indebtedness. They are in need of social justice. The good news to the homeless in the City of Tshwane therefore means provision of shelter, food and water. It means provision of jobs that will ultimately free them from debt.

The homeless in the City of Tshwane need to be released from their captivity. Homelessness leads to some level of oppression. They are prisoners of homelessness. They stay in places they do not like. They are forced to sleep in the streets because they lack shelter. Good news to the captive in the City of Tshwane means provision of shelter that will ultimately release them from the streets of Tshwane. The recovery of sight to the blind in the City of Tshwane does not necessarily refer to people who are physically blind, but also the spiritually blind. The gospel is a means to open people's eyes so that they can open their heart to the Lord Jesus. In addition, being homeless makes one sick. The homeless are exposed to harsh living conditions and unfavourable weather conditions. They are exposed to both the heat in sunny days and rain, and to social classification as other groups in society do not want to associate with them. They need to be restored back to the society and become part of the community.

Finally, the homeless in the City of Tshwane need to hear about the year of the Lord's favour. They need the Year of Jubilee. They need to be released from any form of slavery. The land needs to be given back to their rightful owners so that they do not remain landless which results in homelessness. The debts of the homeless need to be cancelled and the repossessed properties returned to them. They deserve forgiveness in the true sense of the word. The scripture in Luke 4:16-19 needs to be fulfilled to the homeless in the City of Tshwane. They equally need social justice in their lives more than a sermon on the pulpit. Thus, poor people, in simple terms, need new beginnings. They need a true liberator who will deliver them from their foolish ways and who will restore to them genuine wisdom. The most important aspect of the renewal will be the establishment of social justice in their lives (Botha, 2011b:30)

\section{Conclusion}

The literature review on the subject of social justice demonstrated that there is a research gap in approaching the subject from the Biblical perspective, particularly the book of Luke. Equally so, the literature review on the context of Luke 4:16-19 demonstrated that there is a research gap in applying the text to the context of the homeless in the City of Tshwane. To address the above two research gaps, this chapter presented the gospel in Luke 4:16-19 as a mission to the homeless in the City of Tshwane. The chapter read Luke 4:16-19 with the lens of the homeless people in the City of Tshwane. Luke 4:16-19 can be used contextually to address social poverty, captivity, social ills and oppression. To conclude, the gospel as presented in Luke 4:16-19 is relevant to the homeless in the City of Tshwane and can help them to attain social justice.

\section{References}

Anderson, C.L. 2012. Opening doors: Preventing youth homelessness through housing and education collaboration. Seattle Journal for Social. Justice, 11, 457.

Botha, N. 2009. John Calvin in missiological perspective: On church unity and social Justice, Studia Historiae Ecclesiasticae, 35(2), 1-16.

Botha, N. 2010. If everything is contextualisation, nothing is contextualisation: Historical, methodological and epistemological perspectives. Missionalia: Southern African Journal of Mission Studies, 38(2), 181-196. 
Botha, N. 2011. Living at the edge of empire: Can Christianity prevail and be effective? A theological response to the historical struggle between empire and Christianity. Studia Historiae Ecclesiasticae, 37 - Supplement, 133-155.

Botha, N., 2011. Transforming missiology: A dialogue with some reviewers of David Bosch's Transforming mission. Missionalia: Southern African Journal of Mission Studies, 39(1-2), 18-31.

Bruno, C.R. 2010. Jesus is our Jubilee... But how? The OT background and Lukan fulfilment of the ethics of Jubilee. Journal of the Evangelical Theological Society, 53(1), 81.

Chester, T. 2013. Good news to the poor: Social involvement and the gospel. Crossway.

Du Toit, J.L. 2010. Local metropolitan government responses to homelessness in South Africa. Development Southern Africa, 27(1), 111-128.

Eberle, M., Kraus, D., Serge, L. \& Hulchanski, D. 2001. The relationship between homelessness and the health, social services and criminal justice systems: A review of the literature. Vancouver: British Columbia Ministry of Social Development and Economic Security.

Gang, J. 2012. From surprise to shock: A reflection on Luke 4:16-30 and the implications for Seventh-day Adventist Mission. Journal of Adventist Mission Studies, 8(1), 99-106.

Henwood, B. F., Wenzel, S., Mangano, P. F., Hombs, M., Padgett, D., Byrne, T \& Uretsky, M. 2015. The grand challenge of ending homelessness (Grand challenges for social work initiative working paper o. 10). Cleveland, OH: American Academy of Social Work and Social Welfare.

Hurkmans, W.R. 2012. Sabbath, Jubilee, and the repair of the world. Doctoral Dissertation, McMaster Divinity College Hamilton, Ontario.

Jost, J.T. \& Kay, A.C. 2010. Social justice: History, theory, and research. Handbook of Social Psychology.

Mago, V.K., Morden, H.K., Fritz, C., Wu, T., Namazi, S., Geranmayeh, P.,

Chattopadhyay, R. \& Dabbaghian, V. 2013. Analyzing the impact of social factors on homelessness: A fuzzy cognitive map approach. BMC Medical Informatics and Decision Making, 13(1), 94.

Mashau, T.D. 2014. More than just a piece of land: Power dynamics in the land discourse within the City of Tshwane. In T.D. Mashau \& J.N.J. Kritzinger. (eds.). Pavement encounters for justice: Doing transformative missiology with homeless people in the City of Tshwane. AcadSA Publishing.

McCarthy, L. 2013. Homelessness and identity: A critical review of the literature and theory. People, Place and Policy Online, 7(1), 46-58.

Mounce R.H. \& Mounce W.D. 2008. Greek and English interlinear New Testament (NASB/ NIV), Zondervan, Grand Rapids.

Nwaomah, S.M. 2005. Modelling the ministry of Christ in Luke 4:16-19. In contemporary Adventist mission in Nigeria, Journal of Religious Studies, 2(1), 50-59.

Poe, M.A. 2002. Good news for the poor: Christian influences on social welfare Christianity and Social Work, 63-78.
Prior, M. 1995. Jesus the liberator: Nazareth liberation theology (Luke 4.16-30) (№. 26). Burns \& Oates.

Proehl, R.A. 2007. Social justice, respect, and meaning-making: Keys to working with the homeless elderly population. Health \& Social Work, 32(4), 301.

Robbins, V.K. 1996. Exploring the texture of texts: A guide to socio-rhetorical interpretations. A\&C Black.

Shinn, M. 2010. Homelessness, poverty, and social exclusion in the United States and Europe. European Journal of Homelessness, 4(1), 19-44.

Siame, L. 2016. Luke 4:16-30 amidst poverty in Zambia. Doctoral dissertation. Pretoria:University of Pretoria.

Steyn, J. \& Yousaf, A. 2010. Jesus and the marginalized: Attaching pastoral meaning to Luke 4:14-30. Acta Theologica, 30(2), 152-170.

Watson, J. * Cuervo, H. 2017. Youth homelessness: A social justice approach. Journal of Sociology.

Powell, M.A. 1989. What are they saying about Luke? Paulist Press. 